\title{
MENINGKATKAN HASIL BELAJAR PESERTA DIDIK MENGGUNAKAN STRATEGI PEMBELAJARAN AKTIF TIPE GUIDED NOTE TALKING PADA MATERI PERUSAHAAN DAGANG DI KELAS XII IPS 1 SMA NEGERI 2 PEKANBARU
}

(Improving Student Learning Outcomes by Using Active Guided Note Talking Strategies in Trading Company in Class XII IPS 1 SMA Negeri 2 Pekanbaru)

\section{Oleh: Angreta \\ Email : angretajohm@gmail.com}

*) Guru SMA Negeri 2 Pekanbaru

\begin{abstract}
Teaching the learning materials of trading companies the author found that only a few students were active in expressing their opinions, as well as asking questions. Students are even passive, reluctant to ask the teacher if they do not understand the material being taught, unfocused and sleepy when the learning takes place so that the learning outcomes obtained by students on the subject of trading companies are on average 78. Students who complete only about 10 students and 24 students did not complete, while the minimum completeness criteria (KKM) were determined 82. To overcome the problem of lack of attention and activeness of students, the authors tried to apply Using the Guided Note Talking Type Active Learning Strategy to the Material of Trading Companies. This type of research is classroom action research. As for the object of this research are students of class XII IPS 1 Pekanbaru 2 High School. The method of data collection in this study used tests, observation and documentation. The research instrument is a formative test. The results showed an increase in accounting learning outcomes of students of class XII IPS 1 Pekanbaru 2 High School, amounting to 34 students. The application of active Guided Note Talking learning strategies can improve student learning activities. Where the teaching and learning process can be carried out pleasantly so that students can be motivated to learn. The application of active Guided Note Talking learning strategies can improve student learning outcomes with a percentage of the first cycle of $50 \%$, and a second cycle of $85.29 \%$, and the average learning value of students in cycle I 84.38 and cycle II 90.5.
\end{abstract}

Keywords: Learning Outcomes, Economics, Accounting, Talking Guided Note Type Active Learning Strategies

\section{PENDAHULUAN}

Penulis mengajarkan materi pembelajaran perusahaan dagang penulis menemukan hanya sedikit peserta didik yang aktif dalam menyampaikan pendapat, maupun bertanya. Peserta didik bahkan pasif, enggan bertanya pada guru jika tidak paham terhadap materi yang diajarkan, tidak fokus dan mengantuk saat pembelajaran berlangsung sehingga hasil belajar yang diperoleh peserta didik pada pokok bahasan perusahaan dagang ratarata 78 . Siswa yang tuntas hanya sekitar 10 peserta didik dan yang tidak tuntas 24 peserta didik, sedangkan kriteria ketuntasan minimum (KKM) yang diditetapkan 82. Untuk mengatasi masalah kurangnya perhatian dan keaktifan peserta didik maka penulis mencoba menggunakan strategi catatan terbimbing. Strategi catatan terbimbing adalah strategi dimana seorang guru menyiapkan handout dari materi ajar 
yang disampaikan dengan metode ceramah. Handout yang berisi pokokpokok penting dari materi pembelajaran sebagian dikosongkan untuk diisi oleh peserta didik ketika guru menyampaikan materi pelajaran pada saat itu. Berdasarkan uraian pada latar belakang, maka penulis melakukan penelitian dengan judul "Meningkatkan Hasil Belajar Peserta Didik Menggunakan Strategi Pembelajaran Aktif Tipe Guided Note Talking Pada Materi Perusahaan Dagang di Kelas XII IPS 1 SMA Negeri 2 Pekanbaru".

\section{Strategi Pembelajaran Aktif}

Pembelajaran aktif adalah segala bentuk pembelajaran yang memungkinkan peserta didik berperan secara aktif dalam proses pembelajaran itu sendiri baik dalam bentuk interaksi antar peserta didik maupun peserta didik dengan guru dalam proses pembelajaran. Strategi pembelajaran aktif mampu mengajak peserta didik belajar secara aktif selama proses pembelajaran (Silberman, 2005). Pembelajaran aktif akan memperkuat dan memperlancar stimulus dan respon peserta didik dalam pembelajaran, sehingga proses pembelajaran menjadi menyenangkan, dan tidak membosankan (Hartono dkk, 2008). Strategi pembelajaran aktif bertujuan untuk mengoptimalkan penggunaan semua potensi yang dimiliki oleh peserta didik, sehingga semua peserta didik dapat mencapai hasil belajar yang memuaskan sesuai dengan karakteristik pribadi yang mereka miliki.

\section{Strategi Pembelajaran Aktif Tipe Guided Note Talking}

Strategi pembelajaran aktif tipe Guided Note Talking merupakan strategi catatan terbimbing. Catatan terbimbing adalah handout berupa lembaran yang disiapkan oleh guru, berisi rangkuman atau pointpoin penting dari materi pelajaran yang sebagian point-pointnya dikosongkan untuk diisi oleh peserta didik. Handout sebagai media dapat membantu peserta didik dalam membuat catatan ketika seorang guru sedang menyampaikan pelajaran dengan metode ceramah. Gerak fisik yang minimal seperti ini akan lebih melibatkan peserta didik ketimbang jika sekedar menyediakan buku pegangan yang lengkap. Tujuan strategi catatan terbimbing ini adalah agar metode ceramah yang dikembangkan oleh guru mendapat perhatian (Agus suprijono, 2013).

\section{Penerapan Strategi Pembelajaran Aktif Tipe Guided Note Talking Pada Pokok Bahasan Perusahaan Dagang}

Pokok bahasan perusahaan dagang merupakan salah satu pokok bahasan hitungan yang membutuhkan perhatian konsentrasi yang baik dari peserta didik. Oleh karena itu, seorang guru harus melakukan usaha bagaimana agar anak didik tetap berkonsentrasi dalam memperhatikan dan mendengar materi pelajaran yang disampaikan dengan metode ceramah. Salah satunya usaha yang dapat dilakukan adalah dengan menerapkan strategi pembelajaran aktif tipeGuided Note Talking.

Penerapan strategi pembelajaran aktif tipe Guided Note Talking pada pokok bahasan perusahaan dagang dilakukan dalam 4 kali pertemuan. Untuk lebih jelasnya dapat dilihat pada penjabaran berikut ini :

A. Kegiatan Awal

1. Guru menyampaikan salam.

2. Guru memeriksa kehadiran peserta didik.

3. Guru memberikan apersepsi dan motivasi.

4. Guru menyampaikan tujuan pembelajaran dan menyampaikan secara singkat tentang pelaksanaan pembelajaran dengan strategi catatan terbimbing.

B. Kegiatan inti

Untuk pembelajaran yang tidak melakukan percobaan,

1. Guru membagikan handout kepada peserta didik dan memberikan arahan 
kepada peserta didik untuk mengisi titik-titik pada handout.

2. Guru menjelaskan materi pelajaran

3. Guru mengumpulkan handout yang telah diisi kemudian menunjuk seorang peserta didik untuk membacakan handoutnya dan memberikan klarifikasi.

4. Guru membagi peserta didik kedalam 4-5 kelompok dan memberikan LKPD yang dikerjakan secara berkelompok.

5. Guru bersama dengan murid membahas LKPD yang telah dikerjakan secara berkelompok.

C. Kegiatan Penutup

1. Guru menyimpulkan materi pembelajaran yang mengacu kepada tujuan pembelajaran.

2. Guru memberikan evaluasi.

3. Guru memberi tindak lanjut.

\section{METODE PENELITIAN}

Penelitian ini adalah penelitian tindakan (Action Reasech) yang bertujuan untuk meningkatkan hasil belajar peserta didik menggunakan strategi pembelajaran Aktif Tipe Guided Note Talking pada materi Perusahaan Dagang di Kelas XII IPS 1 SMA Negeri 2 Pekanbaru. Rancangan penelitian ini menggunakan model penelitian tindakan dari Kemmis dan Taggart yang terdiri dari empat langkah yaitu perencanaan, pelaksanaan, observasi dan refleksi (Wardhani, 2007: 45).

Penelitian tindakan ini akan dilaksanakan dalam 2 siklus dan setiap siklus dimulai dari planning (rencana), action (tindakan), Observation (pengamatan) dan Reflection (refleksi). Kemudian Langkah pada siklus berikutnya adalah perencanaan yang sudah direvisi, tindakan, pengamatan, dan refleksi dan seterus sampai siklus ketiga.

\section{HASIL PENELITIAN}

\section{Siklus 1}

Rencana tindak "Meningkatkan hasil belajar peserta didik menggunakan strategi pembelajaran Aktif Tipe Guided Note Talking pada materi Perusahaan
Dagang. Penelitian tindakan kelas dilaksanakan di kelas XII IPS 1 SMA Negeri 2 Pekanbaru pada Semester Genap Tahun Pelajaran 2016/2017 yang berjumlah 34 orang peserta didik, terdiri dari 14 peserta didik laki-laki dan 20 peserta didik perempuan.

Penelitian dilakukan sebanyak 2 siklus, setiap siklus terdiri dari 2 kali pertemuan dengan alokasi waktu setiap pertemuan adalah 2 x 45 menit dan pada saat kegiatan pembelajaran berlangsung penulis melakukan observasi terhadap aktivitas peserta didik dengan menggunakan lembar observasi. Penelitian bertujuan untuk meningkatkan hasil belajar ekonomi peserta didik dengan menerapkan strategi pembelajaran aktif Guided Note Talking pada materi perusahaan dagang.

Dalam siklus 1 ini menghasilkan menerapkan strategi pemebelajaran aktif Guided Note Talking diperoleh nilai rata rata hasil belajar peserta didik adalah 84,38 dan ketuntasan belajar mencapai $50 \%$ atau ada 17 peserta didik dari 17 peserta didik yang sudah tuntas belajar. hasil tersebut menunjukkan bahwa pada siklus pertama secara klasikal peserta didik belum tuntas belajar, karena peserta didik yang memperoleh nilai $\geq 82$ hanya sebesar 84,38. Ini jauh dibawah dari presentase ketuntasan yang dikehendaki yaitu sebesar $82 \%$.

2. Siklus 2

Pelaksanaan kegiatan belajar mengajar untuk siklus II dilaksanakan pada tanggal 23 Januari 2017 di kelas XII IPS 1 dengan jumlah peserta didik sebanyak 34 orang. Dalam hal ini peneliti bertindak sebagai guru. Adapun proses belajar mengajar mengacu pada rencana pembelajaran dengan memperhatikan revisi pada siklus 1, sehingga kesalahan atau kekurangan pada siklus 1 tidak terulang lagi pada siklus II. Pengamatan (observasi) dilaksanakan bersamaan dengan pelaksanaan belajar mengajar.

Pada akhir proses belajar mengajar, peserta didik diberi soal tes formatif II dengan tujuan untuk mengetahui tingkat 
keberhasilan peserta didik dalam proses belajar mengajar yang telah dilakukan.Dalam siklus 2 ini menghasilkan diperoleh nilai rata - rata hasil belajar peserta didik adalah 90,5 dan ketuntasan belajar mencapai 85,29 \% atau ada 29 orang peserta didik dari 34 peserta didik yang sudah tuntas belajar. hasil ini menunjukkan bahwa pada siklus II ini ketuntasan belajar secara klasikal telah mengalami peningkatan sedikit lebih baik dari siklus I. Adanya peningkatan hasil belajar peserta didik ini karena peserta didik sudah mulai terbiasa dengan strategi pembelajaran aktif Guided Note Talking yang diterapkan oleh guru. Disamping itu kemampuan guru dalam pengelolaan proses belajar mengajar semakin meningkat sehingga hasil belajar peserta didik mengalamipeningkatan.

\section{Pembahasan hasil Penelitian}

3. Ketuntasan Hasil Belajar Peserta didik Melalui hasil penelitian ini menunjukkan bahwa penggunaan strategi pembelajaran aktif Guided Note Talking memiliki dampak positif dalam meningkatkan hasil belajar peserta didik. Hal ini dapat dilihat dari makin meningkatnya pemahaman peserta didik terhadap materi yang disampaikan guru. Ketuntasan belajar meningkat dari siklus I ke siklus II yaitu masing - masing 84,38 dan 90,5. Pada siklus I ketuntasan belajar peserta didik secara klasikal telah tercapai.

4. Aktivitas peserta didik pada proses Pembelajaran

$$
\text { Berdasarkan analisis data, }
$$
diperoleh aktivitas peserta didik dalam proses pembelajaran dalam setiap siklus mengalami peningkatan. Hal ini berdampak positif terhadap hasil belajar peserta didik yang dapat ditunjukkan dengan meningkatnya nilai rata - rata peserta didik pada setiap siklus. Hal ini diketahui pada saat peserta didik mengerjakan tugas yang diberikan padanya dan Menemukan konsep serta memberi umpan balik dan tanya jawab menunjukan presentase aktivitas yang cukup baik.
Adapun proses pembelajaran pada materi perusahaan dagang dengan menggunakan strategi pembelajaran aktif Guided Note Talking dapat dikatakan bahwa aktivitas peserta didik dalam kategori aktif.

Dengan keaktifan peserta didik selama proses pembelajaran berlangsung dengan menggunakan strategi pembelajaran aktif Guided Note Talking diperoleh hasil belajar peserta didik yang meningkat pada setiap setiap siklusnya. Dengan demikian pelaksanaan strategi pembelajaran aktif Guided Note Talking tidak perlu dilanjutkan pada siklus keTIGA, artinya penelitian ini dilaksanakan hanya dua siklus.

\section{KESIMPULAN}

Berdasarkan hasil penelitian dan pembahasan dapat disimpulkan sebagai berikut :

1. Penerapan strategi pembelajaran aktif Guided Note Talking dapat meningkatkan Aktifitas belajar peserta didik. Dimana proses belajar mengajar dapat terlaksana dengan menyenangkan sehingga peserta didik dapat termotivasi untuk belajar.

2. Penerapan strategi pembelajaran aktif Guided Note Talking dapat meningkatkan hasil belajar peserta didik dengan persentase pada siklus I sebesar $50 \%$, dan siklus 2 sebesar 85,29\%, serta nilai rata-rata belajar siswa pada siklus I 84,38 dan siklus II 90,5.

\section{Rekomendasi}

Guru perlu memilih strategi mengajar yang tepat dalam mengatasi permasalahan dikelasnya. Berdasarkan penelitian yang telah dilaksanakan, maka guru dapat mencoba menggunakan strategi pembelajaran aktif Guided Note Talking apabila memiliki permasalah yang sama seperti kurangnya aktifitas peserta didik dalam menerima pelajaran ekonomi yang bersifat hitungan.

\section{DAFTAR PUSTAKA}

Agus Irianto. 2003. Statistika Konsep 
Dasar dan Aplikasi. Kencana.Jakarta.

Agus Suprijono.2013.Cooperative LearningTeori dan Aplikasi Paikem.Pustaka Pelajar. Bandung.

Deporter,B.,Reardon, M., \& SingerNourie, S. 1999. Quantum Teaching. Allyn and Bacon.Boston.

Hamdani. 2010. Strategi Belajar Mengajar. CV Pustaka Setia.Bandung.

Hartono, dkk. 2008. PAIKEM. ZANAFA. Pekanbaru.

Hisyam Zaini., Munthe, B dan Ayu, A.S. 2008. Strategi Pembelajaran Aktif. Pustaka Insan Madani.Yogyakarta.

Ibrahim, R dan Nana Syaodih S. 1996. Perencanaan Pengajaran. Rineka Cipta. Jakarta.

Kertiasih (2012, November 28). Pengertian Mencatat Berdasarkan Pedagogik. (B.P.Dewi, Interviewer). Moh Nazir.2003. Metode Penelitian. Ghalia Indonesia.Jakarta

Robert Slavin.2008.Cooperative Learning; Teori, Riset dan Praktik. Bandung: Nusa Media.

Roestiyah,N.K. 1989. Strategi Belajar Mengajar. Rineka Cipta. Jakarta.

Sadirman A.S. 1986. Interaksi dan Motivasi Belajar Mengajar. Grafindo. Jakarta.

Silberman M., 2005. Active Learning: 101 Cara Belajar Siswa Aktif. Pustaka Insan Madani.Yogyakarta.

Slameto.2003.Belajar dan Faktor yang Mempengaruhinya.RinekaCipta. Jakarta.

Sudjana. 2005. Metode Statistik. Tarsito.Bandung.

Suharsimi Arikunto. 1988. Pengelolaan Kelas dan Siswa Sebuah Pendekatan Evaluatif. Rajawali Pers. Jakarta.

Syaiful Bahri Djamarah dan Aswan Zain. 2002. Strategi Belajar Mengajar.Rineka Cipta. Jakarta.

Thursan Hakim. 2005. Belajar Secara Efektif. Puspa Suara. Jakarta.

Zulfan Saam. 2011. Psikologi Pendidikan. Pusbangdik. Pekanbaru.
WinaSanjaya, 2008. Strategi Pembelajaran Berorientasi Standar Proses Pendidikan. Kencana Prenada.Jakarta .

Winkel,W.S. 2005. Psikologi Pendidikan Evaluasi Belajar. Gramedia.Jakarta. 
